\title{
THE EMPOWERMENT ACTIVITY FACTORS OF MICRO BUSINESS THROUGH THE REVOLVING FUND UTILIZATION
}

\author{
Arzalvery Agus*, Ravik Karsidi, Mahendra Wijaya, Suwarto \\ Sebelas Maret University, Indonesia \\ *E-mail: erzyvery@gmail.com
}

\begin{abstract}
The micro business empowerment was done by the local government which synergy with local banking was able to drive the local economic increased. This study is a qualitative research approach. The purpose of this study is to know the micro business empowerment factors with the utilization of revolving fund, whereas government as the stakeholders and local banks as the lenders.
\end{abstract}

\section{KEY WORDS}

Business empowerment, store retailer, the revolving fund, government.

The role of micro, small and medium enterprises re-attracted the attention of many observers since the post of economic crisis. It can be seen by many of small and medium enterprise keep survive in the economic crisis in Indonesia. Marimbo (2008) stated that the small and medium business keep struggle during the crisis economic surge. On crisis economic, the small and medium enterprise has proven able to accommodate as $99.45 \%$ by the total of labors or $73.24 \%$ million labors. The role of small and medium enterprises, particularly since the economic crisis able to be viewed as the safety valve on national economic recovery, either to drive the national economic growth or accommodate the labors. The similar opinion is conveyed by Ali (2008) that the small and medium enterprise are the national economic bastion when the sector is ignored means not keeping up the Indonesia bastion. This opinion also supported by Chakrabarty (2012), Rajamohan \& Durairaj (2012) and Mahembe (2011).

Chakrabarty (2012) found the reality that small business played the important role in economic nation with reducing the unemployment and alleviate poverty. Rajamohan \& Durairaj (2012) found that small and medium enterprises are the driver of the business world and economic nation backbone. The sector contributes to the achievement of national GDP, product output, and export. The business micro, small, and middle provide the employment to population. The ratio of labor on capital in micro, small and middle business and the growth of entire sector far higher than large industries. So that, become the requirement for the local government and banking to support the sector. Primarily, the banking needs to override the lending pattern that bases on a traditional asset with lending cash flow patterns base as the priority.

The similar opinion was revealed by Mahembe (2011) that business micro, small and medium played the important role in the economic development through the employment creation, increase the production, the export growth and increase the innovation and entrepreneur skill. However, the current business micro, small and middle facing the big challenge that blocking their growth is access to the business capital. So that, according to Jusuf (1996) the local government and banking have to serve the small business since they have the vital role and maintain the big commitment toward the effort to improve the small business sector.

The government policy related to the development of business micro, small, and medium through the conducive development climate, give the opportunity to make efforts, supporting, protection, and business development as wide as possible. Then able to improve the positions, role and business micro, small and middle potential to realizing economic growth, equity and increase the society's income, make an employment and poverty alleviation. 
The policy is a direction or guidance where the destination of an organization or company want to achieve, related the goal and plan by an organization, government, company, political parties and others. This matter similar with Lasswell (1970) dan Anderson (1979) which stated that the policy is a goal achievement program, values, and direction practices and a set of action that has the certain goal that has to followed and do by the actors as the problem-solving.

The problems faced by much small business like there is no finance administration system and good management, the proposal preparation problem and study of feasibility to obtain the loan by the banks. Since the small business party rarely has a guarantee as for the requirement to borrow the capital, the problem of preparation of business plan, the lack of skilled labor and the lack of information technology skills. That's limitation encourage the unfair competition among the small business actors. A big company that has a large capital, the professional human resource which tends to dominate in the market. So that, need a support by the government parties to give the convenience of a small business such as the provision of capital assistance in order the small business party able to run their business activity.

One of the utilization programs is utilization the revolving fund to financing the business macro, small and middle which do by the local government. It is like Kredit Usaha Pemberdayaan Ekonomi Masyarakat (Business Credit for society Economic Empowerment) which the local policy that shaped of program community empowerment activities for poverty alleviation. The current study aim to knowing the empowerment activity factors of micro business (retailer store) on the utilization of revolving fund by the local government.

\section{THEORETICAL REVIEW}

The society empowerment. The background empowerment of society is due to the powerless of society and inability to develop their own self. This society's inability is also based on its inability to generate initiatives or ideas in order to build society independently and the inability to evaluate development outcomes. So that, able be seen that the final goals of the society empowerment are society independence and to improve the ability to the better life. With another word that the society empowerment is needed during still any powerless of the individual or a society group. which means it is not fully unearthed optimally of ability and potential that owned by an individual or a society group.

The empowerment is a strategy on developing which the implementation be conveyed and developed on daily development. The empowerment more likely developed in the emerging country only. According to Kartasasmita (1997), the empowerment is an effort to improve the society layer in prestige and dignity in the inability to break away from the poverty and backwardness. In another word, empowering is to enable and empower the society. So that the society empowerment should do with: creating an atmosphere that allows the growth of society potential; the effort has to be followed with strengthening the society potential; improve the society participation on decision making; empowering has meaning to protecting.

The Scope of Society Empowerment Activities. According to Mardikanto (2013) practically the society empowerment that does by many parties frequently limited on economic empowerment in order to alleviate poverty and reduce poverty. So that, empowerment is done in form of development of productive activity to increase the income. Besides, in the management science, human occupy a unique element of resources at once as the actors or the manager. Included in the human effort is the whole activities among the strengthening effort or develop the individual capacity, institution, and system.

Mardikanto (2013 b) conveyed that the empowerment activity stages divided become several stage, they are:

1. Determination and introduction the work area. Before doing the activity, the determination of working area need to obtain the agreement among the facilitator team, the local government official, (representative) the local society and another stakeholder (business actor, public figure, NGOs actor, academician, and others). This matter not only to 
avoid the interest conflict among the stakeholders but also to develop the synergy and obtain the endorsement such as participation by the entire stakeholders for the success of the program and community empowerment activities that will be done.

2. Activity socialization is the effort to communicate the society empowerment activity plan that will do in a certain area. Including on activity socialization, need to describe the related parties that will be asked to participate, the division of role is expected, approach, strategy as the steps that will do.

3. Develop the society awareness is the activities that do to bring over of theirs existence, either as the individual and the part of society, as well as the environment condition related the physics environment, technique, social culture, economic and politics.

4. Society organizing, include the leader election and task group that will be formed. The organizing of society important to do since to implement the changes to solve the problem and to improve the problem that can not be done individually but needs the society organizing. Including on the organizing is the role division and developing the partnership network.

5. The implementation of the activities consist of : a) the training to adds and improving the technique knowledge, managerial skill as well as the changes of attitude and insight, b) the activities development, particularly that related to the income increase and protection, preservation and rehabilitation the natural resources, also has an important meaning in order the society be more confident that the assistance role which was given able to improving their life, at least economically.

6. Advocate policy, since all the society empowerment effort (the increased income, the strengthening of bargaining position and others) Require the policy support in public interest parties. The advocate policy needed to obtain the political support and legitimation from the society elite (government official, business actor, public figure, NGO activist, academician and others).

7. Politicization means continually maintain and increasing the bargaining position through the political practices. This matter is needed to obtain and conserving the legitimation and sustainability of the policies that want to be achieved through the society empowerment.

Micro Business. Small industries empowerment is necessary and strategic to anticipate the economic matters, especially to strengthen the national economic structure. The current national economic crisis has an impact to the social stabilization, economic, the political that affected on the large business that is getting worse, while the small business still able to survive on their business activities (Prawirokusumo, 2001). The government need to increase their role in the small industries empowerment as one of national policy strategic, has an important role in driving the economic growth entirely

The definition of micro business according to Decree of the Finance Minister No. 40 / KMK.06 / 2003 dated January 29, 2003, is the productive effort family owned or individual of Indonesian citizens and Has a maximum sale of Rp 100,000,000.00 (one hundred million rupiahs) per year. Micro Enterprises may apply for credit to the bank at most Rp $50.000 .000,00$ (fifty million rupiahs). Characteristics of micro-enterprises (KKMB, 2003):

1. The type of business goods/commodities is not permanent, changeable at any time;

2. The business place is un-permanent, moveable at any time;

3. Have not done yet the financial administration even the simple one, and not separating the family financially and business financial, the business human resources (the business actors) have not the enough of spirit entrepreneurship;

4. The education grade which relative low;

5. Generally, there is no banking access, but some of them have an access to nonbank financial institutions;

6. Generally, have no the business licensing or the other legality requirement includes the NPWP. If has been seen by the banking interest, micro business is the potential market to be serviced, but still many of the micro business difficult to obtain the banking credit service since still does not meet the loan conditions which was set by the bank. 
Partnership Program (soft loan/ revolving fund). According to Tennyson in Wibisono (2007), the partnership is the agreement between sectors whereas individual, group or organization agree to join together to fulfill an obligation or do the certain activities, together bear the risk and profit and reviewing cooperative relationships periodically.

The relation with the Micro Small Medium Enterprises (MSMEs), according to Mardikanto (2010 a), Partnership and Community Development Program conducted by SOEs has been implemented since the early 1990s through the program Pembinaan Usaha Kecil dan Koperasi (Coaching Small Enterprises and Cooperatives or PUKK). Through this program, each SOEs do the partnership activities with the capital assistance pattern such as soft loan / revolving fund, technical coaching, and management as well as product marketing. The current program has been changing become the Partnership and Community Development Program, namely:

a. Partnership Program, in form of soft loan with the interest $6 \%$ per year was given to SMEs group, a cooperative which become its partner;

b. Community Development in form of grants for training programs, promotions and others.

\section{METHODS OF RESEARCH}

The case study often is related to the qualitative research, both have several similarities among others like research deeply, the problem should be preferential, understanding the life completely, and emphasize the natural situation. The current qualitative research the final result is finding the empowerment activities factors of micro business through utilization of revolving fund through synergy between local government and banking. According to Purwanto (2010) case study is the study to analyze the limited case carefully.

This research was conducted on Small Business such as retailer store in Jambi province, Indonesia. In this study, the subject was taken purposively as called information key. The data collection in this study is used observation technique, interview deeply, documentation, and Focus Group Discussion (FGD). That is the characteristics of qualitative research (Bogdan and Biklen, 1982). Selected observation techniques are ordinary, open observation and passive role. Observation is done by observing the activities of retail traders and mentoring the utilization of revolving fund Business Credit for Community Economic Empowerment program.

\section{RESULTS OF RESEARCH}

The empowerment activities factors of retailer through the utilization the revolving fund Business Credit for Community Economic Empowerment program are as follow:

The local government policy is suitable with the vision and mission of local government about Establishment of Coordinating Team for Operation of Business Credit, the policy of local government bank in assisting the distribution report preparation and the realization the credit returning. The policy of establishment the credit executive team that consist of Regional Economic Section, Department of Cooperatives, Industry and Local Government Bank and supported by the availability of operational fund through the Regional Expenditure Budget (APBD).

Condition exclude the retailer store is like the residence description, the condition of trade description and economic condition description region, which gave the positive description to Development of retail trading business through the use of revolving fund of a Local Government program. Besides that, the condition of retailer store generally sell the daily needs product that consumed by the society with the characteristics of the business owned status as the owner as well as the manager. The status of capital owned by the own capital and credit. The number of labors between one to two person even serve the consumer directly. The structure of business capitalization between 3 to 9 million IDR. Source of merchandise in the market and large stores or distributors. The profit by traders 
income a day and the skill still simple that is obtained by generation to generation and spontaneously. Moreover, the resistor factor on the retailer empowerment activities through the utilization of revolving fund by local government program by the retailer side is the human resources limitation, the control less of inventory, inability to anticipate the market opportunities and there is no place to the retailer. While by the program implementation is the small amount of credit, the strict of administration requirement, there is no formal training by the executive team, the facilitator qualification is not certified and occur the temporary postponement in the utilization of revolving fund on that's program. Then the supporting factors are the local government policy support like the utilization of revolving fund of local government program the supporting of the executive team, the capitalization support, and operational activities support. Also, there are a time and place of implementation of the activities which adjusted by Regional Expenditure Budget (APBD) support of Local government and there is in a whole of the sub-district on it. Transportation infrastructure support such as operational transportation and road access as well as a description growth of regional economic condition which is getting better.

The social responsibility of the local government and local bank on the utilization of the revolving fund is to meet the continuous element and sustainable through the programs that have been planned for its implementation. Systematically structured and evaluation-able. The empowerment elements of society can be seen by the participation and initiative of the seller on the utilizing of the revolving fund in second time. The elements of two directions hearing the aspiration of the retailer by the executive team.

Then the understanding of partnership which has fulfilled through the equality or balance principles such as the awakening of mutual respect. Mutual respect and trust accordance with the functions and their roles respectively. The finance information management through the report distribution transparently and realization of the credit refund monthly and mutual benefit is the utilization of credit repayment interest.

\section{CONCLUSION}

The empowerment of micro business had been done accordance with the vision and mission of local government. The synergy between local government, local banking side as well as the small business able to increase the economic growth going to be better. The utilization of revolving fund realizing an economy capable of providing decent employment and livelihoods and providing a solid foundation for sustainable development. This matter means the economic development was directed on the empowerment of natural resources and human resources effectively and efficiency then obtain the output such as a product that able to increase the society welfare.

\section{REFERENCES}

1. Ali, S. 2008. Menkop: Indonesia Bangkrut Kalau UMKM diabaikan. Antara News. Senin 22 Desember 2013.

2. Anderson, James. 1979. Public Policy Making, Second (ed). New York: Holt Renehart and Winston.

3. Bogdan, R.C dan Biklen, S.K. 1982. Qualitative Research for Education. Boston Ally and Bacon Inc.

4. Chakrabarty K.C (2012), "Empowering MSMEs for Financial Inclusion and Growth - Role of Banks and Industry Associations", Organised by the SME Chamber of India, Mumbai, at the 'SME Banking Conclave 2012' on4 February 2012.Bank for International Settlements (BIS) Central Bankers' Speeches.

5. Jusuf, I. 1996. Industri Kecil Dalam Perspektif Pembinaan dan Pengembangan. Airlangga University Press. Surabaya.

6. Kartasasmita, G. 1997. Pemberdayaan Masyarakat: Konsep Pembangunan yang Berakar pada Masyarakat. Badan Perencanaan Pembangunan Nasional. Jakarta.

7. Lasswell, Harold D, 1970. Power and Society. New Haven, Yale University Press. 
8. Mahembe, Edmore, National Credit Regulator (NCR). 2011. Literature Review On Small And Medium Enterprises' Access To Credit And Support In South Africa. Underhill corporate Solutions. Pretoria. South Africa.

9. Mardikanto. 2010 (a). Model-Model Pemberdayaan Masyarakat.UNS Press. Solo.

10. 2013. Konsep-Konsep Pemberdayaan Masyarakat. Program Pascasarjana Pemberdayaan Masyarakat UNS. Surakarta.

11. 2013. Pemberdayaan Masyarakat oleh Perusahaan. Fakultas Pertanian UNS. Surakarta.

12. Marimbo. 2008. Ayo ke Bank dapatkan Kredit UMKM. PT. Ela Media Komputindo. Jakarta.

13. Prawirokusumo, S. 2001. Ekonomi Rakyat (Konsep, Kebijakan dan Strategi) Edisi Pertama. BPFE. Yogyakarta.

14. Purwanto. 2010. Metodologi Penelitian Kuantitatif: Untuk Psikologi dan Pendidikan. Pustaka Pelajar. Yogyakarta.

15. Rajamohan, S dan Durairaj, D. 2012. Empowering Smes Through Priority Sector Advances. International Journal of Business and General Management (IJBGM) ISSN: 2319-2267 Vol.1, Issue 2 Nov 2012 13-20.

16. Undang-Undang Republik Indonesia Nomor 20 Tahun 2008. Usaha Mikro, Kecil dan Menengah.

17. Wibisono, Y. 2007. Membedah Konsepdan Aplikasi CSR. Gresik: Fascho Publishing. 